\title{
RONDÔNIA, UM TRECHO DO GRANDE CERCO DE PAZ: HISTÓRIA INDÍGENA, ESCRITA DA TUTELA INDIGENISTA E HISTORIOGRAFIA DOS PIONEIROS ${ }^{1}$
}

\author{
Eliaquim Timóteo da Cunha ${ }^{2}$ \\ (PPGAS/UFAM)
}

RESUMO: Este artigo tem por objetivo apresentar a problemática inicial da pesquisa sobre a participação do Serviço de Proteção aos Índios - SPI na formação de Rondônia. O texto é formado pela apresentação das categorias: escrita da tutela indigenista e historiografia dos pioneiros. Está em fase inicial, sendo desenvolvido na pesquisa de mestrado e atualmente faz parte da pesquisa de doutoramento do autor. Nesse momento o escopo é demonstrar os tópicos básicos da discussão referente às escritas que classificaram os povos indígenas e as escritas que não os citaram ao que se refere à formação de Rondônia.

Palavras-chave: Rondônia. Tutela Indigenista. História Indígenas. Historiografia dos Pioneiros.

ABSTRACT: The objective of this article is to present the initial problem of the research on the participation of the Protection Service for Indians in the formation of Rondônia. The text is formed by the presentation of the categories: writing of the indigenous guardianship and historiography of the pioneers. It is in the initial phase, being developed in the master's research and are currently part of the doctoral research of the author. At that moment the scope is to demonstrate the basic topics of the discussion referring to the writings that classified the indigenous peoples and the writings that did not mention them as far as the formation of Rondonia is concerned.

Keywords: Rondônia. Indigenous Protection. Indigenous History. Historiography of the Pioneers.

\section{INTRODUÇÃO}

Rondônia nem sempre foi Rondônia.

A discussão aqui estabelecida é a formação de Rondônia. A problemática está em sua fase inicial. Para tanto, apresento de forma pontual a escrita da tutela indigenista e a historiografia dos pioneiros. Essas escritas e historiografia indicam a formação de alteridades e as categorias classificatórias direcionadas aos povos indígenas. Com a história indígena podemos compreender a formação de Rondônia e de quais maneiras e em quais campos essa formação tem sido entendida. Nesse sentido, em outro trabalho foi apresentada a trajetória dos indígenas Cassupá em Rondônia, Timóteo da Cunha (2017), onde demonstro alguns aspectos das políticas indigenistas e os entendimentos dos indígenas sobre essas políticas. A pesquisa aponta os silenciamentos produzidos quanto aos povos indígenas.

\footnotetext{
${ }^{1}$ A primeira versão desse texto foi elaborada como o primeiro capítulo "Rondônia, um trecho do grande cerco de paz” da minha dissertação, intitulada: “'Quando esse tal de SPI' chegou: O Serviço de Proteção aos Índios na formação de Rondônia”. Foi defendida no PPGAS/UFAM em 2016.

${ }^{2}$ Estudante de doutorado no Programa de Pós-Graduação em Antropologia Social da Universidade Federal do Amazonas, Brasil. Bolsista CAPES. E-mail: cunha.antropologia@gmail.com
} 
As produções indígenas estão em destaque na problematização trazem novos questionamentos com o distanciamento da postura tutelar. Para compreender os aspectos da presença indígena nos projetos de ocupação na região em destaque evidenciar-se-á as distinções entre as produções de alteridades realizadas pelas ações indigenistas e as produzidas pela história indígena.

As narrativas indígenas têm ocupado inúmeras agendas de pesquisas com recursos interdisciplinares das Ciências Sociais no Brasil. Por exemplo, destacam-se as coletâneas que reúnem diversas pesquisas realizadas nas últimas décadas: "Histórias dos índios no Brasil" Carneiro da Cunha, (1992); "Amazônia, Etnologia e História Indígena” (Viveiros de Castro \& Carneiro da Cunha, 1993); "Pacificando o Branco: Cosmologias do contato no NorteAmazônico" (Albert \& Ramos, 2002); “A viagem da volta: etnicidade, política e reelaboração cultural no Nordeste indígena" Oliveira Filho, (2004); "A presença indígena na formação do Brasil" (Oliveira Filho \& Freire, 2006), entre outras obras. Essas pesquisas têm dado atenção a perspectiva que parte dos conceitos indígenas, quando os povos indígenas ${ }^{3}$ constroem, em seus próprios termos, questionamentos quanto a "história oficial", produzindo alteridades e construindo representações de si mesmos ${ }^{4}$.

Ainda são incipientes as investidas ao tema que pode ser intitulado como "a atuação do SPI em Rondônia”. Aqui, me refiro sobre o contato estabelecido pelos agentes de Estado vinculados a programas de colonização estabelecidos no século XX. Encontram-se trabalhos que abordam esse tema de forma tangencial, quer dizer, o fio condutor é uma determinada população indígena e não a instituição indigenista, no caso o SPI, ou ainda a Fundação Nacional do Índio - FUNAI 5 .

\footnotetext{
${ }^{3}$. No decorrer desse texto utilizo o termo "povo" seguindo a definição da convenção 169 da OIT e pelo motivo de inúmeras organizações se autodeclaram com essa categoria. Encontramos as descrições realizadas por Tomei \& Sewpston: "Durante três anos, a OIT trabalhou para a adoção da Convenção, discutido se na nova Convenção Mudaria por "povos" o termo "populações" utilizado na Convenção 107. A decisão de usar o termo "povos" resultou de longas discussões e consultas dentro e fora das reuniões. Acordou-se finalmente que o termo correto seria o de "povos" já que se este reconhece a existência de sociedades organizadas com identidade própria, em vez de simples agrupamentos de indivíduos que compartem algumas características raciais ou culturais" (Tomei \& Sewpston, 1999: 29).

${ }^{4}$. O debate requer amadurecimento que virá no decorrer da realização desta pesquisa e das disciplinas, ao que diz respeito às produções de alteridade, etnogêneses, emergência étnica, etnicidades, fricção interétinica., etc, Peirano, (1999), Barth, (1998), Wagner, (2010), Lévinas, (2004), Todorov, (1994), Bartolomé, (2000), Cardoso de Oliveira, (1963, 2000). Esta revisão bibliográfica se faz necessária, mesmo com perspectivas distintas, uma vez que é preciso amadurecer os alcances e limites desses conceitos e métodos.

${ }^{5}$ A literatura etnológica tem muito a contribuir na composição dessa problemática, como por exemplo, Price, (1972), Moser, (1993, 1997), Leonel, (1996), Maldi, (1989, 1991, 1996, 1997), Mindlin, (1985), Pinto, (2009), Vander Velden, (2010a, 2010b), Vilaça, (2006), França, (2012), Dal Poz Neto, (1991, 2004) entre outras.
} 
Antes de apresentar os elementos acionados por Roquette-Pinto para delimitar o território geográfico denominado Rondônia, no campo da etnologia, este território é abordado pela categoria áreas etnográficas. A região é dividida em: "Mamoré-Guaporé”, "Amazônia Centro-Meridional" e “Aripuanã”, todas essas áreas estão inseridas ao "Anel Tupi” Melatti, (2001). Nas literaturas historiográfica e etnológica encontramos definições que procuraram caracterizar a região com perspectivas cartográficas amalgamadas a características culturais, como por exemplo, "Mosaico da Amazônia Meridional” Brasil, (2001), "Complexo Cultural Maricó” Maldi, (1991), “Área Etnográfica Guaporé” Galvão, (1960), “Área Etnográfica Guaporé" Melatti, (2001). No bojo dos trabalhos que objetivam caracterizar a região de Rondônia, a pesquisa de Vander Velden, (2010: 120) mapeou a produção etnológica sobre os grupos Tupí na região de Rondônia, faz destaque a contribuição de Roquette-Pinto.

Essa diversidade de povos indígenas da região está presente timidamente nos textos do SPI, em destaque nos relatórios dos Postos Indígenas. Entretanto, a perspectiva tutelar e assimilacionista desta agência, onde a estratégia de homogeneizar as diversidades era um modo de reforçar as relações de poder, muitos etnônimos foram aglutinados uns aos outros, principalmente no contexto dos deslocamentos pelo território induzidos pelo SPI. Este é o caso dos Cassupá, conforme foi estudado em (Timóteo da Cunha, 2014, 2016, 2017).

A proposta de trabalho de Schettino (2005: 147-187) em atualizar as informações sobre as áreas etnográficas, a fim de apoiar os grupos de trabalho da FUNAI nos processos de identificação e delimitação de terras indígenas, mediante o levantamento de dados etnográficos, é pertinente por considerar as mudanças, os fluxos migratórios regionais e os grandes projetos latifundiários que afetam diretamente as demarcações de terras indígenas. A reflexão de Schettino (2005) aponta os vários processos de transformações recentes do território de Rondônia.

A temática do contato entre o Estado e os Povos Indígenas é, no mínimo, interessante (pode-se dizer como muitos etnólogos gostam de afirmar "é bom para pensar") para compreender e questionar o lugar dos povos indígenas diante as dinâmicas contemporâneas dos projetos de colonização, nacionalização e ocupação da região e também para repensar o lugar das agências políticas presentes nas memórias e nas reinvindicações étnicas. 


\section{RONDÔNIA, UM TRECHO DO GRANDE CERCO DE PAZ}

Na transição da monarquia portuguesa para a república brasileira havia uma geração que tomou para si a incumbência de construir e, em determinadas regiões, reconstruir o país. Desvinculando-se de séculos da dominação portuguesa, uma fatia da geração teve suas formações escolares nesse período de transição, entre as duas últimas décadas do século XIX e na primeira do século XX.

Esse tipo de mudança, seja por meio de combates revolucionários ou ainda do modo como foi no Brasil, requer um complexo de variados mecanismos políticos. Não se trata apenas de medidas oriundas de uma cúpula onde meia dúzia de pessoas tomam decisões. É muito mais complexo. Agora imagine mudar a concepção, por exemplo, da ideia de trabalho, tendo como referência o sistema escravocrata que perdurou por séculos. Ou ainda como definir o que é do Brasil? Quem é do Brasil? Quem está apto a responder tais perguntas? Cada conceito precisava ser redefinido. Nesse bojo, a geração que marchava rumo ao progresso, a formação da Nação, e não mais na condição de colônia, tem questões práticas como as estradas, a comunicação e etc. Porém, existiam aqueles que estavam no caminho, os diferentes, os "selvagens", os "fetichistas", "os índios do Brasil”. Aqueles que a igreja não conseguiu "civilizar", conforme a nova perspectiva. Era necessário readequar o lugar do indígena aos novos projetos.

Por meio do SPI foi construído um complexo de canteiros de obras, com a incumbência de contribuir na construção do Brasil apartando-se da colonização portuguesa, orientando-se pela perspectiva positivista e nacionalista. Um dos seus engenheiros foi Cândido Mariano da Silva Rondon; ele formulou uma descrição dessas ações com o projeto grande cerco de paz, segue uma parte dessa descrição que compôs o relatório do Ministério da Agricultura, Indústria e Comércio - MAIC de 1910:

Serviço que tem para campo de ação toda a vastidão do território nacional, desdobrando-se em uma sequência de atos que não podem ser interrompidos, sob pena de malogro de todo o trabalho em andamento, de todo esforço despendido, Serviço que se dirige a um tempo à natureza selvagem do solo e à natureza selvagem de seu habitante, necessitando do emprego de métodos experimentais de cultura e da prática de processos científicos de civilização no desbravamento das terras e no trato da alma humana, Serviço que, para ser eficaz, para desenvolver-se, para produzir e consolidarse, carece de um exercício continuado distribuído por uma multiplicidade de órgãos convergentes, um tal Serviço, assim caracterizado, atenta a enormidade do território nacional, ou melhor, a disseminação das tribos indígenas na grande órbita de sua vida 
nômade por esse imenso território, só pode ser executado por crescido número de funcionários de várias categorias, num grande cerco de paz, num assédio extenso e paciente. (Rondon, 1910: 259).

A ideia expressada por Rondon inspirou o título do trabalho de doutoramento de Souza Lima (1992) "Um grande cerco de paz: poder tutelar, indianidade e formação do Estado no Brasil". Sobre os aspectos físicos e simbólicos desse projeto, Souza Lima diz que

A imagem do grande cerco de paz revela-se em toda a sua complexidade nas palavras do militar, sumarizando numerosos mecanismos ainda hoje em ação: técnica militar de pressionamento e forma de manter a vigilância, ao mesmo tempo assédio de um inimigo visando cotar-lhe a liberdade de circulação (...). (...) Além de defesa contra os de fora de cerco, como num cercado para as crianças, estabelecendo limites e constrições aos por ele incluídos/excluídos, numa amplitude que deveria justificar um numeroso quadro administrativo de fato hoje em dia existente. Modo tático de sublimação da guerra e forma de denegar a violência aberta, construída sobre os alicerces da ciência da época e não mais da religião, a imagem do cerco, estabelecido pelo terceiro elemento constituído idealmente pela administração (...) da divisão imposta, produzindo índios e civilizados. (Souza Lima, 1995: 131).

Efetivamente não existiu a construção de um cerco de cimento e barro. Porém, o "grande cerco de paz" descrito por Rondon é metáfora com intuito em construir a imagem que ajudaria a explicar o que viria a ser o SPI. Ao longo de sua atuação, a própria ideia de um cerco não aparece nos registros da agência. Sobre as construções físicas, podem-se elencar os seguintes elementos: as práticas burocráticas (produções de documentação, registros das atividades, bem como mecanismo de vigilância para garantir as execuções das mesmas), as estradas; as demarcações de fronteiras; as unidades sociais como os Postos Indígenas, formados por roças e pomares, criação de animais, construção de casas, escolas, enfim todo o mecanismo das políticas de incorporação do índio à nação brasileira. O cerco, mesmo na condição de metáfora, não foi construído de forma contínua, o SPI - pela descrição em seus documentos - esteve ausente em várias regiões; um exemplo é o estado do Acre.

Ainda assim, o grande cerco de paz é imagem apropriada para abordar o tema. Nesse sentido, para ajudar a descrever essa estampa, recorro a um conto de Franz Kafka (2002) "Durante a construção da grande muralha da China". A narrativa é conduzida por um dos trabalhadores da construção, que assume a condição de historiador e mesmo em sistema de censura, ele arrisca descrever parte do sistema de construção do empreendimento.

O narrador afirma: “(...) nós, da construção, conhecemos o assunto de outro ângulo e nos calamos" Kafka, (2002: 83), a narrativa estabelece um contraponto entre as lendas que 
envolve a construção a muralha e a versão oficial. Devido à censura, o narrador identifica-se apenas como um dos trabalhadores sem indicar o nome próprio, assumindo o anonimato. Tal empreendimento deveria ser executado por gerações, a muralha era uma proteção, a materialização da ideia de unidade, como se fosse uma "uma ciranda do povo", conforme denomina o narrador.

No caso do SPI não houve um projeto para relatá-lo como um todo, não existiu trabalhador que revestisse a capa de Clio para descrever os detalhes da agência, bem como a hierarquia e o habitus $^{6}$ dos seus agentes. Houve sim, publicações. Porém, não com o intuito detalhístico do cotidiano.

Darcy Ribeiro (1962) foi quem montou projeto para explicar a política indigenista. No entanto, é preciso compreender o contexto político daquele momento, dando continuidade na escrita ufanista sobre os feitos do SPI $^{7}$. A título de exemplo, cito três obras que podem ser consideradas como "produções sobre o SPI, feitas pelos seus agentes". Pela ordem de publicação: Rondon, 1954, "Índios do Brasil", são três volumes, esta obra tem o aspecto de relatório, repletos de fotografias com o intuito comprobatório da civilização. Tem um teor de divulgação do trabalho do SPI, distante de critérios críticos. A segunda obra "Rondon conta sua vida", foi organizada por Esther Viveiros (1969) trata-se de compilados de registros feitos por Rondon, isto é, não é uma obra editada por Rondon ${ }^{8}$. A terceira obra que indico é a tese de Freire (2005) dedicada a história de vida de sertanistas. Esse trabalho tem uma postura crítica ao indigenismo e procura trazer à tona o ponto de vista dos sertanistas que vivenciaram as práticas do SPI.

\footnotetext{
${ }^{6}$. Sobre as técnicas corporais, Marcel Mauss (2003) designa o termo habitus para compreender a interiorização das diferentes técnicas corporais. Para Mauss: "Assim, durante muitos anos tive a noção da natureza social do "habitus". Observem que digo em bom latim, compreendido na França, "habitus". A palavra exprime, infinitamente melhor que "hábito", a "exis" (hexis), o adquirido e a "faculdade" de Aristóteles (que era um psicólogo). Ele não designa hábitos metafísicos, a "memória" misteriosa, tema de volumosas ou curtas e famosas teses. Esses "hábitos" variam não simplesmente com os indivíduos em suas imitações, variam, sobretudo com as sociedades, as educações, as conveniências e as modas, os prestígios. É preciso ver as técnicas e a obra da razão prática coletiva e individual, lá onde geralmente se vê apenas a alma e suas faculdades de repetição". Mauss, (2003: 404). Já Bourdieu afirma: "O habitus é, com efeito, princípio gerador de práticas objetivamente classificáveis e, ao mesmo tempo, sistema de classificação de tais práticas. Na relação entre as duas capacidades que definem o habitus, ou seja, capacidade de produzir práticas e obras classificáveis, além da capacidade de diferenciar e apreciar essas práticas e esses produtos (gosto), é que se constitui o mundo social representado, ou seja, espaço dos estilos de vida". (Bourdieu, 2008: 162). As duas perspectivas são orientadoras para pensar sobre o habitus indigenista, que me refiro às técnicas apreendida para realizar as políticas indigenistas.

${ }^{7}$ para ter contato com uma crítica detalhada sobre esse trabalho de Ribeiro $(1962 ; 1979)$ sugiro a leitura de Souza Lima (1985).

${ }^{8}$ Sobre esse trabalho sugiro a leitura de Souza Lima (1990).
} 
Por sua vez, o material que vamos encontrar sobre os detalhes e cotidiano dessa agência são os registros que abordam questões pontuais, cumprindo com as práticas administrativas e não com o teor historiográfico. Porém, os relatórios elaborados pelos agentes indigenistas dedicavam-se a várias críticas sobre os arranjos políticos e as condições de realização das políticas indigenistas com esforços de aprimorá-las. Esses relatórios são os principais materiais utilizados nas pesquisas sobre o SPI, pois tratam da construção de determinado conhecimento, com específica forma e conteúdo, fundamentados em conceitos, métodos e técnicas na execução da tutela indigenista; uma linguagem usada de forma moderada e instituída pelo ufanismo do SPI na produção da sua versão oficial.

O projeto político de redefinir o lugar do indígena "no destino da nação brasileira" esteve repleto de introjeção da poética nacionalista republicana. Essas práticas e discursos foram peças chave para construção de unidades sociais e, claro, construção de fronteiras físicas e culturais. Nessas diferentes figurações, podemos questionar qual o lugar do indígena nessa formação, pois, aquelas mudanças são frutos de práticas e representações do indigenismo e seus dispositivos ${ }^{9}$.

\section{RONDÔNIA: UM PROJETO DE EDGAR ROQUETTE-PINTO}

No ano de 1905 Edgar Roquette-Pinto, aos 21 anos de idade, se formou na Faculdade de Medicina do Rio de Janeiro. Nesse mesmo ano foi admitido como professor no Museu Nacional, onde foi diretor entre os anos de 1926 a 1935 encerrando trinta anos de trabalhos na instituição ${ }^{10}$.

Em 1915 Edgar Roquette-Pinto apresentou algumas de suas experiências vividas na Expedição "Serra do Norte" - ocorrida entre os meses de julho a novembro de $1912{ }^{11}$. Quatro anos depois, foi publicado "A Rondônia" na Revista do Brasil, naquela oportunidade o texto é

\footnotetext{
9. Por exemplo, o SPI esteve subordinado a diferentes Ministérios, nos seus primeiros vinte anos, integrou o Ministério da Agricultura, Indústria e Comércio. Entre 1930 a 1934, esteve no quadro do Ministério do Trabalho. Em meados dos anos 1930 (1934 a 1939), ficou vinculado a Inspetoria de Fronteiras no Ministério da Guerra. Na década de 1940, retorna ao reformulado Ministério da Agricultura e, ainda naquela década, passou a compor o Ministério do Interior Brasil, $(1918 ; 1930 ; 1934 ; 1939 ; 1940)$. Ter em vista essas diferentes passagens ajuda a compreender os momentos de intensificação ou diminuição da atuação do SPI em determinadas regiões, pois estava fortemente ligada a organização orçamentária do Ministério que compunha.

${ }^{10}$. Sobre o contexto da admissão e trajetória Roquette-Pinto no Museu Nacional, sugiro a leitura da tese Souza, (2011).

${ }^{11}$. Para mais detalhes sobre essa expedição, sugiro a leitura da dissertação Santos, (2011), ver também Colferai, (2013).
} 
construído com abordagem resumida sobre a Expedição. No ano seguinte, em 1917, aquelas experiências formaram a primeira edição do livro "Rondônia: etnografia, etnologia" publicado no vigésimo volume do periódico Arquivos do Museu Nacional ${ }^{12}$.

No contexto de sua criação o livro Rondônia possuía duplo papel: fazer ciência e política. A descrição territorial mencionada por Roquette-Pinto foi o traçado da primeira expedição da Comissão Rondon, programada em 1907. Em sua origem, o termo Rondônia esteve ligado ao contexto da formação do Brasil no século XX. A primeira utilização do termo foi proposta de Edgard Roquette-Pinto (1915), quando formulou o projeto da construção de uma província antropogeográfica ${ }^{13}$ denominada como Rondônia. Segundo ele, designava a zona compreendida entre os rios Juruena e Madeira sendo cortada pela "Estrada Rondon". O ato de delimitar a "província antropogeográfica" fazia mais que descrições, faziase projeto político que visava ações estatais. Para o autor os aspectos que justificavam a criação da província eram de ordem geológica, botânica, zoológica, antropológica e etnográfica que a referida região era composta.

A pauta proferida por Roquette-Pinto, era: "O que nos falta é conhecer o que se tem descoberto e conquistado" Roquette-Pinto, (1913: 588; 1927: 85), frase publicada em dois textos no intervalo de quatorze anos. E esse conhecimento não é mera contemplação da exuberância da natureza ou da diversidade das organizações sociais. Esse conhecer é tomar o controle. Nesse sentido, a construção de cartografias novas, com renomeações dos rios, das estradas, homenageando os nomes que representavam os projetos republicanos e não mais os nomes dos santos e reis conforme era ante da República, foi empreendimento governamental e científico. Fronteiras foram reforçadas e outras construídas, assim, demarcaram-se circulações de pessoas, mercadorias, ideias e circulação de projetos políticos. Conhecer, naquele contexto é dominar.

Pela primeira vez era formulada uma circunferência territorial na administração republicana que homenageava um brasileiro: trata-se de Cândido Mariano da Silva Rondon. Da proposta inicial de Roquette-Pinto até a criação do Território Federal de Guaporé (1943), o SPI protagonizou políticas indutoras de mudanças na gestão de territórios e promoveu

\footnotetext{
12 Alguns dos exemplares desse periódico estão disponíveis em: $\underline{\text { http://www.portaldeperiodicos.sibi.ufrj.br/unidades_museu.htm. }}$

${ }^{13}$ Mesmo que Roquette-Pinto não tenha detalhado qual influência o auxiliou na sua definição antropogeografia, não é errado afirmar que a obra "Geografia do Homem (Antropogeografia)" de Friedrich Ratzel, teve grande influência na obra de Roquette-Pinto. Nesse sentido é importante ter a vista os trabalhos de Raymundo Lopes "Antropogeografia" (1956).
} 
amálgamas entre as políticas tutelares e as ciências com perspectivas positivistas que formularam categorizações às sociedades indígenas dentro de escalas do evolucionismo social. Deste modo, promoveram-se novas cartografias sociais e fortes transformações territoriais.

Rondônia teve várias edições em português e uma em alemão, em 1954, dou destaque a terceira, sexta e sétima edições que trouxeram modificações significativas, como por exemplo, acréscimos de mapas e comentários de outros pesquisadores; outras edições tiveram poucas modificações feitas pelo autor. A sexta edição, quando em 1975 compôs o trigésimo nono volume do projeto editorial "Brasiliana", quando fora incluída "Carta Ethnographica da Rondônia”. Naquela oportunidade a obra teve contribuições, com acréscimos de detalhes em notas de rodapé, feitas por Heloisa Alberto Torres, Alberto José de Sampaio, Olímpio da Fonseca Filho, Fábio Werneck, Raimundo Lopes, Álvaro Osório de Almeida e Melo Leitão. A tradução Alemã foi feita por Etta Becker-Donner.

Nesse sentido, mais que uma obra, Rondônia é uma das expressões predicativas da geração de projetistas da nação brasileira ${ }^{14}$ atuante no início do século XX. Geração que configura uma complexa rede de interdependência ideológica na formação do Estado Brasileiro. Sobre a geração que tomou para si a incumbência de trabalhar na construção do Brasil no século XX, trago a fala de Ramiz Galvão ${ }^{15}$ quando Roquette-Pinto foi incorporado ao quadro do IHGB, em 1913:

(...) O ilustre consocio [Roquette-Pinto], que acabamos de ouvir e aplaudir, é um dos poucos da nova geração que se votam amorosamente aos estudos etnográficos, e ainda bem que sua predileção científica tomou este rumo. A seara, a que me refiro, foi até aqui mais aproveitada pelos sábios e viajantes europeus do que por filhos da nossa terra. (...). É tempo ainda, mas cumpre não perdê-lo, de completar o estudo das tribos que conservam o tipo ancestral e mantem língua costumes e crenças primitivas. Tudo isso será, talvez dentro de um século, pura arqueologia, mas, por isso mesmo, se faz mister que a geração contemporânea redobre de esforço para deixar a posteridade a notícia completa da raça autóctone. Ela não deixa monumentos, sem papiros, nem pagodes, nem inscrições que transmitam ao futuro a sua história. Captar, portanto, esta lympha [sic] preciosa que ainda corre da nascente e que amanhã se terá sumido da

\footnotetext{
${ }^{14}$. Recorro à reflexão de (Pareschi, 2002) sobre a ideia de projetismo. "O projetismo como uma forma de intervenção social especialmente vinculada à ideologia do desenvolvimento, manifestando estruturas tecnoburocráticas e as hierarquias nelas contidas, imprimindo uma dinâmica própria, geralmente alheia às condições reais em que é aplicada, contrariando, de certa forma, os objetivos que o justificam". (2002: 108).

15. Ramiz Galvão (Benjamin Franklin Ramiz Galvão, Barão de Ramiz), foi médico, professor, filólogo, biógrafo e orador. Nasceu em Rio Pardo - RS em 1846 e faleceu no Rio de Janeiro - RJ, em março de 1938. Dirigiu a Biblioteca Nacional e também foi sócio e orador perpétuo do Instituto Histórico e Geográfico Brasileiro.
} 
terra, é uma obra de alto valor que merece os nossos aplausos e cuja gloria não devemos deixar a estranhos. (Galvão, 1913: 599-600).

Outra frase famosa sobre o tema é do próprio Roquette-Pinto:

Venho das últimas gerações da monarquia. Assisti aos 5 anos as primeiras festas da República. Penso que o país deve um grande serviço à minha geração: foi a primeira a descrer das 'fabulosas riquezas' do Brasil, para começar a crer nas 'decisivas possibilidades do trabalho'. Recebemos a noção de que um moço bem nascido e bem criado não devia precisar trabalhar (...). Ouvimos ainda o eco dos eitos. Diziam-nos que nosso céu tem mais estrelas que os outros (...). Minha geração começou a contar as estrelas. E foi ver se era verdade que nos nossos bosques havia mais vida. E começou a falar claro aos concidadãos. Com minha geração, o Brasil deixou de ser tema de lirismo. (Roquette-Pinto, 1939: 45).

Ter em vista a categoria "geração" auxilia o olhar para o amálgama do que foi considerada vocação política e vocação científica. Quando se encontra essa categoria, ao menos no contexto abordado, se vê que ao utilizá-la marcam a linha temporal entre passado, presente e futuro, desta forma produzem a autoimagem. O discurso de Roquette-Pinto na cerimônia onde ele foi incorporado ao IHGB deixa claro o de seu lugar de fala, demonstrando seus posicionamentos quanto aos estudos e políticas direcionados aos indígenas, aos sertanejos, a ciência e aos cientistas. Posiciona-se ao lado dos vários cientistas daquela época, que compreendiam o papel da ciência, atuando por meio de aparatos administrativos, na construção de Estados Nacionais, e nesse caso, em um projeto definitivo de construção da nação brasileira. Esse não é um projeto isolado. Ele é um dos vários que compõem a formação do Estado-Nação no Brasil no início do século XX.

Em suma, o Livro "Rondônia" (1917) já teve dezenas de leituras. Aqui, torna-se necessário tecer alguns comentários devido a sua importância na proposta dessa pesquisa. É importante, pois é a primeira vez que "Rondônia" foi idealizada, um espaço específico com populações específicas e com potenciais para o progresso da "Nação Brasileira". Esse projeto só foi possível, no contexto do processo de formação do Estado brasileiro no século XX. Os conhecimentos geográficos e etnológicos acumulados pela atuação do SPI e do IBHG foram fundamentais para pôr em prática os rascunhos de Roquette-Pinto. Ressalto que livro não é fruto de um relatório destinado ao governo, em primeiro lugar é produzido como um fruto de pesquisa e seu objetivo era divulgar trabalhos científicos, no entanto, fazia parte de uma ideologia de entender "os índios do Brasil" para haver condições de conduzi-los em direção à civilização. 


\section{A HISTORIOGRAFIA DOS PIONEIROS}

A forte característica do que nomeio como historiografia dos pioneiros é a escrita ufanista, os personagens estudados por esses estudiosos (alguns com formações acadêmicas, outros foram pesquisadores autodidatas) são aqueles considerados como ordenadores da política e das organizações das unidades estatais. Portanto, trata-se de explicar a formação de Rondônia com base em feitos individuais e exaltando determinada elite política de forma heroica. Relembrando que "pioneiro" faz parte deste arcabouço ufanista, e é uma categoria acionada nessas literaturas.

Por ora, trato das obras dedicadas a explicar a formação do Território Federal do Guaporé. Essas dividem resumidamente a formação de Rondônia em três fases. A primeira é a criação do Território Federal de Guaporé, (Decreto-Lei No 5.812 13/07/1943), sendo uma formação do desmembramento do sul do estado do Amazonas e do norte do estado do Mato Grosso; a segunda fase quando passa a ser denominado como Território Federal de Rondônia, (Lei $N^{\circ} 21.731$ 17/02/1956), e a terceira e última fase trata-se da elevação a estado (Lei complementar $N^{\circ} 41$ 22/12/1981). Entretanto, quando citamos uma lei ou decreto, temos que ter claro que para chegar nessa etapa (Lei, Decreto, Portaria) aquela ideia passou por várias agências e é fruto de uma complexa rede de poderes e saberes.

O decreto é um dos elementos das redes de disputas; é necessário ter em vista os alcances das abordagens jurídicas e das abordagens sociológicas, como observou Weber (1964). Além disso, a crítica deve ser feita visando às ações dos agentes de Estado que encarnavam os diferentes projetos de "desenvolvimento" e "integração" voltados a região.

Encontramos pesquisas com abordagens que exaltam e reproduzem os agentes de Estado com "pioneiros", "desbravadores" e "civilizadores", adjetivos que correspondem ao arquétipo do herói nacional, calcados no ufanismo dos "pioneiros", Menezes, ([1979] 2001: $105)^{16}$. O termo "andanças de Rondon" reduz e descontextualiza o longo e engenhoso processo de conquista territorial por aquele agente. Menezes ([1979] 2001), chama os

\footnotetext{
${ }^{16}$ Nas suas andanças Rondon percorreu grande parte dessas esticando de Cuiabá ao Amazonas a sua linha telegráfica. Encontrou o bravo soldado, por estas paragens, os construtores da lendária Estrada de Ferro Madeira Mamoré [E.F.M.M], um dos mais arrojados empreendimentos levados a cabo no mundo. A nacionalização ocorreu em 10 de julho de 1931. Outros desbravadores despontam, sobressaindo-se entre eles os padres salesianos pelo vulto da obra que empreenderam no campo social (...). Foi durante a [segunda] guerra que Rondônia se constituiu em Território Federal com a primitiva denominação de Guaporé. O então Presidente Getúlio Vargas, que aí esteve em 1940, a 13 de setembro de 1943 assinou o Decreto-Lei n. 5812, cônscio da alta responsabilidade que assumia com o futuro da região Menezes, (2001: 105. Destaques meus).
} 
trabalhadores da E.F.M.M ${ }^{17}$ de "bravo soldado", amenizando o contexto de exploração e as péssimas condições sanitárias diante às doenças tropicais. Mais adiante, no texto de Menezes, continua: "Sua linha telegráfica" se refere a Rondon, o uso do pronome possessivo "sua" indica como se a linha telegráfica fosse a conquista de um homem só; outro adjetivo é "Outros desbravadores despontam", Menezes se refere aos salesianos, e aí encontramos um ponto importante de sua obra, a ideia do desbravamento. Quando diz "outros desbravadores" adjetiva os personagens mencionados anteriormente, como Rondon, os construtores da Estada de Ferro, as construções das linhas telegráficas, misturando contextos diferentes.

Em 1978, Menezes participou do concurso "Monografia sobre a História, Geografia e o momento atual do município de Porto Velho". Foi o único inscrito, mas não foi laureado com a premiação. Entretanto, o prefeito Luiz Gonzaga Farias Ferreira e os secretários de educação Jerzy Badocha em conjunto com algumas empresas incentivaram a publicação da obra "Retalhos para a História de Rondônia" Menezes, ([1979] 2001: 23-24).

Por vezes, o estilo de escrita lembra um agente de Estado exercendo suas funções, produzindo uma propaganda dos feitos dos seus superiores na hierarquia estatal. No entanto, trata-se de uma pesquisa de um autodidata, sendo o autor considerado como um pioneiro. Menezes, ([1979] 2001, p. 24) ${ }^{18}$. Essas frases iniciam a introdução da obra, considero um esforço de Menezes para se situar enquanto um estudioso da história de Rondônia. Outro exemplo, dentro da historiografia dos pioneiros, é “Terras de Rondônia” encontrado em

\footnotetext{
${ }^{17}$ A Ferrovia foi construída no auge da produção gomífera, com acordos entre Brasil e Bolívia, tinha como finalidade agilizar o transporte da borracha extraída da região do Alto Madeira, do rio Mamoré e da Bolívia. Existiram inúmeras tentativas, por várias empresas, para sua construção que foi iniciada em 1878. No entanto, houve várias interrupções e foi finalizada somente em 1912, quando a borracha da região havia desvalorizado. Havia um conflito sobre a posse do território que hoje é o estado do Acre; o conflito foi concluído com o tratado de Petrópolis em 1903 e o Acre foi anexado a Federação. Cf. Costa, (1940). Na década de 1930 a companhia inglesa declarou falência e o Brasil assumiu a administração da Ferrovia, suas atividades foram interrompidas aos poucos e tendo fim em 1966. Para a história da Ferrovia Cf. Craig, (1947), Ferreira, (1987), (Fonseca \& Teixeira, 2002), Fonseca, (2014). No segundo capítulo deste trabalho são descritas as atividades de desmonte da Ferrovia com a compra e venda dos dormentes que sustentavam os trilhos, usando mão de obra indígena com intermédio do SPI.

${ }^{18}$. (...) não sou escritor, por isso o trabalho contém muitas imperfeições que vão sendo corrigidas à medida que forem sendo observadas, mas acredito que servirá para consultas das pessoas que queiram conhecer alguns detalhes da História do Território Federal de Rondônia (...). Envaide-me ter sido o primeiro a expor-me às canseiras de fazer pesquisa nesse campo, que é muito vasto e cheio de dificuldades, para conseguir alguns documentos. O que pude obter está aí para os estudantes aprimorarem os estudos das coisas de sua terra. (...) O Território de Rondônia ainda não tem sua história nem sua geografia. Nas escolas são ensinadas essas disciplinas baseando-se apenas nos conhecimentos que tem alguns professores das cousas de nossa Terra, por isso muitas narrações feitas pelos Mestres não encontraram embasamento para firmar a sua veracidade. (...) isso não é a História e a Geografia de Rondônia, são apenas retalhos colhidos aqui e ali. Alguém teria que começar. Isso estou fazendo, agora. (Menezes, ([1979] 2001: 24).
} 
O Território Federal de Rondônia foi criado por Decreto-Lei número 5.812 de 13 de setembro de 1943, com o nome de Guaporé, mudando posteriormente para o de Rondônia, pela Lei $\mathrm{N}^{\mathrm{o}} 21.731$, de 17 de fevereiro de 1956, em homenagem ao marechal Cândido Mariano da Silva Rondon. (Lima, 1997: 13).

Esse trecho é citado, pois dá o tom da abordagem sumarizada que forma a obra. Como já dito, minha proposta é problematizar as relações, os conhecimentos produzidos para se chegar à formação de Rondônia. Caso as pesquisas deem continuidade em apenas parafrasear decretos e leis, reproduzir-se-ão os sistemas de classificação dos agentes de Estado. O intuito é promover avaliações atentas e minuciosas aos processos de colonização.

Lima (1997) no preâmbulo da terceira edição define que o livro "Terras de Rondônia é um trabalho didático". O objetivo da obra foi "divulgar o Território federal de Rondônia, sua potencialidade econômica, sua história, sua gente, não só nos demais Territórios e Estado da União, mas junto ao próprio povo de Rondônia" ${ }^{19}$. Com essa citação vemos para quem o livro é dedicado. Faz-se necessário problematizar como os estudos sobre a região são construídos e quais temas são eleitos para construir essa história e principalmente quais temas ficam de fora.

Além de Rondon, teremos em tela Aluízio Ferreira. Encontram-se nessas obras a busca de construir uma espécie de mito fundador, preparam o cenário, os personagens maquiados de forma apropriada a ocasião, suas falas estão no ritmo adequado, até mesmo os imprevistos são acrescentados a trama ${ }^{20}$.

Para compreender os projetos de colonização é importante entender os projetos de lei construídos após Vargas, como o Projeto de Lei 008/1947 e Decreto-lei 411/69. Outro fator indispensável para esta pesquisa é ter em vista que os Territórios Federais foram criados e mantidos em contextos políticos relacionado à integração do território nacional, à proteção

\footnotetext{
${ }^{19}$ Esperamos ser útil colegas de magistério, aos estudantes, às autoridades, aos empresários e a todas as pessoas que vieram de todas as regiões brasileiras, participar na construção de mais novo Estado na Amazônia Ocidental, superando seus problemas vivendo e fazendo sua história e contribuindo com seu trabalho, com sua inteligência para o seu desenvolvimento, o desenvolvimento da Amazônia e sua efetiva integração ao Brasil (Lima, 1997: $13)$.

${ }^{20}$ No dia 13 de setembro de 1943, atendendo a um chamado que lhes fizera o Presidente da República, Aluízio Ferreira compareceu em Petrópolis, onde encontrou Getúlio Vargas passeando nos jardins do Palácio Rio Negro, na companhia de um Oficial da Marinha, seu Ajudante de Ordens, e de dois menores moradores na vizinhança do Palácio e que haviam pedido para tirar uma fotografia com Getúlio. Depois de receber os respeitosos cumprimentos do então major Aluízio, o Presidente, juntando as mãos das crianças como um compromisso formal de testemunho, anunciava que naquele dia seriam criados os territórios e convidava Aluízio para governar o Território do Guaporé (...) por sugestão do Ministro de Viação e Obras Públicas, Mendonça Lima, receberia o nome de Rondônia, em homenagem ao general Cândido Mariano da Silva Rondon: este, ao ter conhecimento da indicação, obstinadamente recusou a homenagem, desgostoso com o governo Vargas. Hugo, (1995: 49-50).
} 
das fronteiras e a sua ocupação. Essa escala mais ampla demonstra que esses projetos estavam muito além de um acordo entre Aluízio Ferreira e Getúlio Vargas.

Nessas obras citadas encontra-se uma perspectiva que constrói Aluízio Ferreira como uma figura heroica, como se a criação daquele Território Federal fosse o trabalho de apenas um homem. Com isso, excluem da discussão o contexto político e as estratégias geopolíticas mais amplas, como a construção de cinco Territórios Federais nas regiões de fronteira ${ }^{21}$, negligenciam as imposições das ações de Estado diante as sociedades indígenas e comunidades tradicionais.

Portanto, ao apresentar os elementos já expostos sobre a historiografia dos pioneiros, problematizando a cristalização de certas informações, como os Decretos-Leis objetivam mostrar que a construção de Rondônia apresenta eventos, aparentemente dispersos, que podem ser observados como parte de um processo de formação de Estado.

Nesse sentido, o SPI foi uma das agências que fazem parte da configuração deste território e sua ausência na historiografia apresentada, fazem parte de descrever nessa configuração quais práticas, representações, agências e burocracias agem para a formação desse território.

Outro estudo importante é "Na Rondônia Ocidental” publicado em 1938 pelo então Major Frederico Augusto Rondon. Esse livro é matéria de avaliação para pensar "ciência de governar", pois encontramos séries de reivindicações para o Estado se fazer presente naquela região "tão rica e desconhecida". Outra reivindicação, escrita desde o prefácio, em 1937, é a criação de um instituto que seja responsável pela divulgação dos trabalhos que buscam

dissipar, definitivamente, a bruma da incerteza geográfica no Sertões fronteiriços e interiores do País. Pela divulgação dos estudos e das cartas que já possuímos e pelo prosseguimento das explorações (...). Na verdade, tal obra exigiria, antes de tudo, um órgão coordenador. E a falta deste órgão por si só explica a situação atual, no domínio geográfico. Imagino um instituto geográfico nacional, organizado pelo Exército com a necessária colaboração civil (...) (Rondon, Frederico, 1938: 17).

No ano de 1939, um ano depois da publicação do livro "Na Rondônia Ocidental", passou a ser publicada a Revista Brasileira de Geografia, editada pelo Instituto Brasileiro de Geografia e Estatística - IBGE. A Revista executou várias das ideias apresentadas por Alfredo Rondon.

\footnotetext{
${ }^{21}$ Decreto-Lei ${ }^{\circ}$ 5.812, de 13 de setembro de 1943. Cria os Territórios Federais do Amapá, do Rio Branco, do Guaporé, de Ponta Porã e do Iguassú. Ver Benevides, (1946).
} 


\section{OS ESTUDOS SOBRE O SERVIÇO DE PROTEÇÃO AOS ÍNDIOS}

É preciso referir o conjunto de pesquisas dedicadas ao estudar o SPI com premissas subjacentes a questionamentos do papel social e político das ciências na formação do Brasil. Existem duas vertentes da escrita sobre o $\mathrm{SPI}^{22}$. A primeira vertente foi produzida no período da vigência do SPI (1910-1967), e são caracterizados pelo ufanismo nacionalista e pelo humanismo positivista, os compiladores dessa escrita podem ser divididos nas seguintes categorias: etnólogos, militares, políticos, jornalistas, engenheiros e propagandistas.

A segunda vertente é o conjunto de pesquisas sobre o SPI realizadas por antropólogos, sociólogos e historiadores; desenvolvidas desde a década de 1980. Essas pesquisas fazem um recorte histórico do período entre 1910 (criação do SPI) chegando a 1930 (vésperas do início do "Estado Novo").

Ao indicar essas pesquisas, mesmo de forma breve, o propósito é mensurar a respeito das fontes e dos recursos para leitura das mesmas. Não se trata de realizar uma interpretação detalhada das trajetórias dos autores e autoras.

As caraterísticas que aproximam as pesquisas sobre o SPI são os temas que envolvem Estado, poder, dominação, formação do Brasil e políticas indigenistas. Os trabalhos aqui reunidos terão indicações dos critérios utilizados para apontar suas aproximações. Os critérios são: objetivos, fontes e métodos, correntes teóricas e conceitos, período de realização da pesquisa, universidades onde as pesquisas foram desenvolvidas.

O caráter geral dessas pesquisas se fundamenta na restituição dos aspectos paradoxais da tutela indigenista. Aqui, parto do ponto "o paradoxo da tutela", tratado por Oliveira Filho (1988) e de modo geral, as demais pesquisas sobre o SPI, mesmo que não tenham como foco principal "o paradoxo da tutela", esbarram no tema; uma vez que expõem e discutem sobre as disputas políticas e econômicas que envolviam as políticas indigenistas do SPI. É interessante lembrar da crítica elaborada por Oliveira Filho (1988: 24-59), quando apresentou a problemática de sua tese, sobre "os obstáculos ao Estudo do Contato". Uma leitura realizada

\footnotetext{
${ }^{22}$. Neste ponto indico os trabalhos de Arruda, (2003; 2011), Bagolin, (2009), Bernardino, (2013), Bigio, (2003), Freire, (1990; 2005; 2007; 2011), Gagliardi, (1989), Erthal, (1992), Hoerhann, (2005; 2011), Martins, (2012), Melo, (2007), Oliveira, Humberto, (1947), Oliveira, J. P. (1988; 2011), Peres, (1992; 2011), Ribeiro, (1962; 1977), Rocha, (2003), Rondon, Cândido (1953), Rondon, Frederico (1938), Santos, (2009), Souza Lima, (1985, 1992, 1995, 2011).
} 
por Oliveira Filho, (1988, p. 226) pesquisa feita sobre o regime tutelar do SPI junto aos Ticuna, auxilia a compreender algumas das contradições e impasses dessas políticas.

Em todas as suas fases o SPI estava fundado na missão denominada como "proteção aos índios", essa dita proteção ora ocorria com programas que visavam a sobrevivência física conforme apontou Souza Lima, (1985), ocorria também com a efetivação da incorporação do indígena a sociedade brasileira por meio da agricultura, e transformações nos usos dos recursos naturais e usos territoriais. No entanto, é necessário compreender de quais formas essas ações ocorriam e quem as realizava, pois ao passo que visavam mediar conflitos eram promovedoras dos mesmos.

Os índios, "os fetichistas", os tutelados eram os protegidos. Os protetores guiados pelo humanismo positivista tinham os quesitos contra as ameaças que vinham a galope, o progresso era eminente e a expansão do capitalismo na América Latina causaria a extinção dos indígenas como afirmava os construtores do SPI e outros pensadores como Ribeiro (1962). A proteção poderia ser tão somente um esforço de preservação física Souza Lima, (1985) na tentativa em minimizar os impactos do progresso. Ainda na categoria das ameaças estão os "gananciosos", - termo utilizado pelos agentes do SPI, para indicar aqueles que exploravam a mão de obra e os territórios indígenas sem o aval do SPI.

Em 1918, ocorreram mudanças ministeriais e houve o desmembramento entre o Serviço de Proteção aos Índios e a Localização dos Trabalhadores Nacionais, passando a ser duas frentes de ação, cada uma com um "público alvo". Contexto no qual houve reorganização do Serviço de Povoamento no Brasil. O primeiro (Serviço de Proteção aos Índios) ficou sob jurisdição da seção de obras, custeio, e desenvolvimento das povoações indígenas e o segundo (Localização dos Trabalhadores Nacionais) passou a executar suas atividades vinculadas a seção de obras, custeio, conservação e desenvolvimento dos centros agrícolas.

Num plano ideal, todos os objetivos da proteção foram mantidos durante a existência do SPI. Faz-se necessário problematizar, que a busca para realizar essas metas era fruto das conveniências e/ou limitações do SPI diante as realidades políticas, econômicas, naturais e relações estabelecidas com as sociedades indígenas e com aquelas que não se identificavam e não eram identificadas como indígenas. $\mathrm{Na}$ execução da proteção, proposta pelo SPI, geravam-se conflitos diante as relações assimétricas entre tutores e tutelados, educadores e educandos. 
A proteção fraternal proposta pelos formuladores e executores do SPI voltava-se para os denominados "inimigos do progresso"; aqueles que impediam a "evolução" do indígena. Toda a ameaça era descrita tendo o ufanismo nacionalista como contraponto da argumentação, isto é, elementos formuladores da moral nacionalista, o altruísmo, os desbravamentos dos sertões, por parte dos funcionários, estavam de um lado da balança, enquanto do outro lado estavam os gananciosos que exploravam as terras e a mão de obra indígena. Porém, desde que fosse solicitado e negociado junto ao SPI, elites regionais, com empreendimentos particulares para exploração e comercialização de recursos naturais, tais como látex, guaraná, pescados, gado e madeira entre outros investimentos que invadiam territórios indígenas e em variadas proporções utilizavam mão de obra indígena, passavam a serem investimentos de grandes feitos em prol do progresso do Brasil. Desta maneira, ver-seá as definições, voláteis, do que vinha a ser ameaça e proteção.

Grande parte das pesquisas dedicadas a estudar o SPI optou pelo recorte histórico entre as décadas de 1910 (fundação do SPI) a de 1930 (início do "Estado Novo"). A historiografia brasileira define este período como sendo "república velha" ou "primeira república". Por outro lado, o objetivo que proponho exige um recorte histórico a partir da década de 1940, pois como veremos mais adiante, os conhecimentos produzidos pelo SPI contribuíram para construção dos Territórios Federais, nessa oportunidade dou atenção a Rondônia.

\section{A ESCRITA DA TUTELA INDIGENISTA}

A escrita tem um lugar de destaque no conjunto de materiais para os estudos das políticas indigenistas; caracterizando-se como um dispositivo de dominação. A prática de registrar e arquivar as atividades dessas políticas é hoje matéria tanto para os pesquisadores, que repensam a formação do Brasil e o papel social da ciência nesse processo, quanto para os agentes da política indígena que utilizam esses documentos em suas reivindicações. Em consonância a noção de "escrita de Estado", formulada por Chartier (1990) ${ }^{23}$. A noção escrita da tutela indigenista trata do esforço de discutir que tal escrita atendia aos campos administrativos, políticos e científicos, expressando o poder tutelar, bem como os conhecimentos e o habitus indigenistas inseridos no processo de formação do Brasil que

23. “(...) é necessário reconhecer a estreita imbricação, na escrita de Estado, entre o simbólico e o instrumental. A presença multiplicada ou monumental dos escritos é sempre, em si mesma, a marca de uma dominação para todos tornada visível (...)" (Chartier, 1990: 218). 
transformaram territórios étnicos. A escrita da tutela indigenista auxilia na discussão sobre o sistema classificatório do SPI e se caracterizam na elaboração dos registros das atividades cotidianas dessa agência indigenista. As pesquisas dedicadas ao SPI têm mostrado que para pensar sobre o contato estabelecido pelo SPI é interessante compreender os métodos, os critérios, o sistema de classificação, que os agentes indigenistas usavam para registrar essas atividades.

Podemos identificar dois campos da escrita da tutela indigenista. O primeiro seria formado com divisões entre as áreas de Botânica, Zoologia, Sanitarista e Etnologia. Esses registos eram base para exposições no Museu Nacional, publicações no Boletim do mesmo Museu e eram também base de exposições em congressos realizados principalmente por Roquette-Pinto e por Rondon, no tocante a Etnologia. Um exemplo é a obra "Os Índios do Brasil".

O outro âmbito da escrita da tutela indigenista, que será abordado neste trabalho, diz respeito aos registros administrativos quanto a reorganização do SPI e a construção da Nona Inspetoria Regional. Em 1943 foram criados os Territórios Federais ${ }^{24}$ e, em 1945, é criada a Nona Inspetoria Regional - IR 9, do SPI, com sede em Porto Velho e jurisdição sob o Território Federal de Guaporé. A criação do Território e da Inspetoria, ambas divisões políticas e administrativas, foram recortes territoriais do Amazonas e do Mato Grosso. As reformas realizadas nas Unidades do SPI eram embasadas nos conhecimentos acumulados pela prática indigenista e veremos a legitimidade dos agentes especializados em índios induzindo mudanças sociais. A criação da Nona Inspetoria esteve ligada à determinada reforma no SPI. Os Postos Indígenas desta Inspetoria foram resultado do rearranjo de Postos que atuavam sob jurisdição da Inspetoria do estado do Amazonas e Território do Acre (Primeira Inspetoria Regional - IR 1) e de Postos sob a jurisdição da Inspetoria do estado do Mato Grosso (Sexta Inspetoria Regional - IR 6). Essas Unidades podiam ser transferidas de lugar e ser renomeadas conforme os arranjos políticos e os conflitos regionais, seguindo as orientações do Serviço (Timóteo da cunha, 2017).

Entretanto, antes de seguir para este ponto, trago uma leitura sobre o texto "Etnografia" produzido por Rondon a pedido do Instituto Brasileiro de Geografia e Estatística, compondo o tópico “inquéritos geográficos”, foi publicado em 1940 na Revista

\footnotetext{
${ }^{24}$ DECRETO-LEI N ${ }^{\circ}$ 5.839, de 21 de setembro de 1943. Dispõe sobre a administração dos Territórios Federais do Amapá, do Rio Branco, do Guaporé, de Ponta Porã e do Iguassu.
} 
Brasileira de Geografia. Naquela oportunidade, Rondon apresentou suas concepções sobre os alcances da Etnografia, tendo como orientadores Comte, Lowie, Taylor e os irmãos Humboldt, ou seja, o evolucionismo. Os princípios desses autores citados por Rondon são:

O mais sábio dos Filósofos [Augusto Comte] afirma: 'Quando o Positivismo houver saneado uniformemente o planeta humano, estas distinções orgânicas (de raças) tenderão a desaparecer, em virtude mesmo de sua origem natural, e sobretudo mediante dignos casamentos. A combinação crescente dessas raças nos proporcionará, sob a direção sistemática sacerdócio universal, o mais precioso de todos os aperfeiçoamentos, aquele que diz respeito ao conjunto de nossa constituição cerebral, assim tornada mais apta para pensar, agir, e mesmo amar'. (Rondon, 1940: 596).

Robert Lowie em seu 'Manual de Antropologia Cultural', livro atualizado, pelo qual melhor se pode conhecer o método moderno de pesquisas etnográficas faz considerações aliás já anteriormente admitidas por Tylor, sobre a época em que o homem começara a fabricar utensílios de uso indispensável a sua existência (...). Com o grande etnólogo Tylor podemos incluir a vida humana, a grosso modo, em três grandes estados: selvagem, bárbaro e civilizado, caracterizando tipicamente a marcha da evolução de gênero humano. (Rondon, 1940: 599).

No primeiro trecho da citação são afirmações que lembram as argumentações da fundação do SPI, diz da busca pelo "aperfeiçoamento", as ideias de miscigenação ${ }^{25}$. Rondon parte da premissa que a Etnografia estava intrinsicamente ligada a Antropologia, e esta requeria atenção da Biologia, Sociologia e Moral, partindo da filosofia positivista Comtiana.

$\mathrm{Na}$ perspectiva colonialista, Rondon citando Guilherme Humboldt indica consequências benéficas calcadas na conquista:

O argumento é lógico - 'A conquista, um longo hábito de conveniência comum, a influência de uma religião estrangeira, mistura de raças, mesmo quando tenha tido lugar com um pequeno número de emigrantes mais fortes e mais civilizados, têm produzido um fenômeno que se nota simultaneamente nos Continentes. Por exemplo: duas famílias de línguas inteiramente diferentes podem estar compreendidas numa mesma raça e vice-versa. Entre povos de origem totalmente diferente podem ser encontrados idiomas de um mesmo tronco de línguas'. (Rondon, 1940: 598).

A primitividade era fato basilar que justificava as políticas indigenistas do SPI. Rondon considerava os trabalhos de Robert Lowie como sendo os mais avançados e completos no que se refere ao tema, ele afirmou:

Penso, com Rivet e Metreaux, que o conceito moderno, estado atual dos conhecimentos e dos métodos de pesquisa referente à Etnografia, é o que Robert Lowie adotou para construir o 'Quadro da vida indígena'. Desprezando hipóteses teóricas, aqueles mestres da Etnologia mostram, em termos claros e rigorosos, empregar para ter uma idéia integral, exata, da primitivadade humana, caracterizada pela vida do Íncola. (Rondon, 1940: 616). [O destaque foi dado pelo autor].

\footnotetext{
25. Sobre os temas eugenia e miscigenação Cf. (Lima \& Hochman: 1996, 2004), (Santos: 2002, 2008) e (Seyferth: 1985, 2008).
} 
Rondon não menciona as críticas construídas contra o evolucionismo, mesmo as críticas feitas por Lowie ${ }^{26}$, como foi citado anteriormente, não cita também a possibilidade de outras correntes metodológicas que não a evolucionista. Rondon chega a indicar os museus dos Estados Unidos, mas não cita os trabalhos de Boas, se refere apenas Lowie. É possível afirmar que suas escolhas que não estavam apenas no âmbito acadêmico, mas antes disso eram embasamentos para a efetivação da Tutela sob os indígenas. $\mathrm{O}$ ponto central era a orientação metodológica distanciando-se do método da "antropologia de gabinete", mas ainda calcado nos preceitos evolucionistas.

Ainda naquele texto, continua Rondon elencando os principais pontos do método etnográfico de Lowie:

Esse conceito e esse método consistem: $1^{\circ}$ - Insistir nas observações detalhadas da atividade das tribus mais primitivas, estudando a fundo a sua vida no seu próprio 'habitat'. $2^{\circ}$ - Ligar as culturas ou civilizações de um tipo rudimentar às de estruturas mais complexa, passada ou presente para, por comparação, surpreender os efeitos dos fenômenos de contacto das civilizações correspondentes, onde a lei da imitação revelará todo o profundo senso da realidade. [...]. $3^{0}$ - Minha opinião a respeito da situação atual das pesquisas efetuadas no Brasil e do emprego dos métodos modernos quanto à Etnografia, é que o Museu Nacional se orienta, depois da República, pelo método moderno das pesquisas diretas, deixando de lado o método histórico-cultural, tradicionalmente empregado antigamente por todos os Museus e Academias em que se estudava a Antropologia com especialidades etnológicas e etnográficas. (Rondon, 1940: 616).

Quanto à citação ao Museu Nacional, Rondon referia-se a Roquette-Pinto, Heloisa Alberto Torres ${ }^{27}$ (diretora do Museu entre 1940 e 1950). Está em tela caraterísticas da escrita etnocêntrica e civilizada carregada de legitimidade para o exercício da Tutela. Não se estava preocupado com o que as pessoas realmente faziam, o escopo era enquadrar em qual escala da primitividade estavam os povos indígenas. O que era considerado "pesquisa direta" ou pesquisa "in loco", como fez Roquette-Pinto, sendo este o exemplo sempre citado.

O primeiro tópico da citação acima, "observações detalhadas da atividade das tribus mais primitivas”, para pesquisas contemporâneas esses detalhes são incipientes, pois naquele momento, as "observações detalhadas" atendiam aos objetivos de conduzir os povos

\footnotetext{
26. A indicação bibliográfica feita por Rondon é: "Manuel d`Antropologie Culturelle. Traité de Sociologie Primitive", Trad. de E. Metreaux.

${ }^{27}$. Sobre Eloisa Alberto Torres Cf. (Corrêa, 2003).
} 
indígenas à civilização. Claro que são registros importantes, mas não podemos lê-los de maneira descontextualizadas das políticas do SPI.

Adam Kuper (2008:182), em sua história dos estudos antropológicos sobre a sociedade primitiva, fez considerações sobre Lowie que são relevantes para compreender alguns aspectos que não foram abordados na leitura seletiva feita por Rondon. Com "leitura seletiva" quero dizer que as críticas ao evolucionismo não foram citadas por Rondon e também não demonstrou exemplos claros de trabalhos realizados com o método de Lowie. Ainda no texto de Kuper:

(...) Franz Boas e seus alunos produziram um bombardeio de contra-exemplos etnográficos que eram especificamente designados a explodir os arrimos que sustentavam o modelo de Morgan (...) Os textos de Lowie, publicados nos de 1920, resumiram uma geração de crítica anti-evolucionista da escola de Boas: a família era universal; os laços territoriais eram sempre significativos; as sociedades matrilineares não eram necessariamente menos desenvolvidas que as sociedades patrilineares; $o$ totemismo era uma fantasia. Homem cuidadoso Lowie reteve algumas das idéias mais antigas (...) mas ele escreveu como um revolucionário de sucesso, ou assim ele acredita. (Kuper, 2008: 299).

Em 1946 e 1953 Rondon organizou, em três volumes, o livro "Índio do Brasil". Os livros são formados pela reunião de várias expedições realizadas desde o início da Comissão das Linhas Telegráfica e Estratégica de Mato Grosso ao Amazonas (1890-1930) e seguindo com as atividades do SPI até aquele momento, portanto são registros de 50 anos. O primeiro volume "Do Centro ao Noroeste e Sul de Mato Grosso", o segundo "Cabeceiras do Xingu/Rio Araguaia e Oiapóque" e o terceiro intitulado "Norte do Rio Amazonas".

O Conselho Nacional de Proteção aos Índios - CNPI, reuniu uma série de publicações de relatórios de expedições diversas, desde a Comissão Rondon e das atividades do $\mathrm{SPI}^{28}$. A rede de relações que viabilizou essas publicações foi tecida entre o Departamento Administrativo do Serviço Público - DASP, Ministérios da Agricultura e da Fazenda e o próprio CNPI.

Esses são alguns dos pontos indicados para dimensionar sobre a escrita da tutela indigenista. Em outro trabalho (Timóteo da Cunha, 2016, 2017) situei os empreendimentos da colonização promovida pelo SPI com as atividades das expedições auríferas de Urucumacuã, apresentando uma rede de relações e agentes com práticas e discursos visando o controle de recursos naturais e circulação de pessoas. Tendo a experiência da trajetória do grupo Cassupá como fio condutor da discussão.

\footnotetext{
${ }^{28}$. Sobre a construção do CNPI ver (Freire, 1990).
} 


\section{CONSIDERAÇÕES}

Nesse espaço não coube discutir de forma mais detalhada sobre a historiografia dos pioneiros e também sobre as pesquisas pós essa geração "pioneira". Foi apresentada a formulação da problemática que dá base para a pesquisa de desenvolvo neste momento. As questões que me levaram a discutir sobre indigenismo em Rondônia foram, principalmente, os deslocamentos vivenciados pelo povo indígena Cassupá no estado de Rondônia, fronteira entre Brasil e Bolívia. Com isso, discuto sobre a formação de Rondônia.

Neste texto, em alguns trechos pode parecer que não houve resistência, porém convido a leitura do texto "da tutela ao protagonismo" onde discuto sobre os deslocamentos vivenciados pelo povo indígena Cassupá, entre 1940 a 2013, no estado de Rondônia, fronteira entre Brasil e Bolívia. A pesquisa se embasa em leituras de documentos produzidos pelas instituições estatais (SPI, FUNAI e INCRA), bem como documentos produzidos e organizados pelos indígenas, isto é, não realizei prolongado trabalho de campo com os Cassupá. Não obstante, nos documentos elaborados pelos indígenas encontram-se explicações e questionamentos das vidas que foram silenciadas nas ações das políticas indigenistas. $\mathrm{O}$ processo pelo qual os Cassupá produzem, organizam e fazem releituras de documentos denomino como "narrar Cassupá". O rompimento do silêncio, a partir da escrita, ressoou nas políticas indigenistas e nas políticas indígenas. Destarte, tratando-se do temário "Estado Brasileiro e os Povos Indígenas", a pesquisa traz para discussão não somente a documentação produzida pelos agentes de Estado, além disso, e principalmente, é preciso ler e ouvir as vozes e as narrativas documentadas e as selecionadas pelos indígenas sobre as relações que julgam relevantes em suas trajetórias. O protagonismo indígena, neste caso, é evidenciado no narrar Cassupá. Narrar polifônico. O presente estudo demonstra isso partindo da observação de que este narrar é amálgama de diferentes lugares e referências sociais, é resultante dos critérios eleitos pelos indígenas, quer dizer, são eles quem falam sobre si e releem documentos que falaram sobre eles (Timóteo da Cunha, 2017).

Os Cassupá vivem na capital de Rondônia, Porto Velho, desde 1973, após vários deslocamentos provocados pelas políticas indigenistas desde a década de 1940. A discussão é estabelecida a partir do seguinte processo: A) Os Cassupá e o Serviço de Proteção aos Índios (1940 a 1967), quando passaram a viver em trânsito nos Postos Indígenas presentes no rio Guaporé, trabalhando com caucho, extração de madeira, coleta de castanha, construção de 
estradas e entre outras atividades; B) O descolamento promovido pela FUNAI, instalando-os na cidade de Porto Velho; C) As reivindicações, iniciadas em 1995, que visavam o reconhecimento étnico junto a FUNAI, por meio do Ministério Público, com o apoio do CIMI; D) Nos anos de 2012 e 2013, é delimitada uma Área, a partir da parceria da FUNAI e IBAMA com a Usina Hidrelétrica Santo Antônio Energia, visando integrar os Cassupá ao programa de medidas compensatórias da hidrelétrica no rio Madeira. Essa trajetória, explicada ponto de vista dos indígenas, faz parte do campo "produções indígenas".

É interessante pensar também sobre a concepção de violência dentro do sistema de classificação do SPI. Sob a perspectiva da agência indigenista, as transformações promovidas não eram consideradas violentas. Contudo, as ocupações territoriais sem o aval do SPI eram ameaças. O mesmo ocorria em relação a força de trabalho indígena. Ao trabalhar nas atividades do SPI como parte de um programa de nacionalização, a agência indigenista apontava como uma ação redentora, como uma dádiva. Novamente, se os indigenistas trabalhavam para empresas que não tinham o aval do Serviço era praticada a exploração da mão de obra.

As políticas indigenistas construíram cartografias sociais de forma singular tendo em vista sua expertise. As mudanças nos territórios étnicos estavam amalgamadas com vários projetos de reocupação e reconhecimento territorial. As transformações no uso e ocupação territorial estavam inseridas em vários projetos políticos nacionais.

Neste trabalho o foco foi dado para escrita da tutela indigenista e parte da historiografia dos pioneiros, pois os questionamentos da história indígena e das reivindicações étnicas formulam bases para pensar sobre a formação da Amazônia e principalmente a de Rondônia. Mesmo que de forma sumária, a pesquisa demostra as relações entre dos agentes de estado, os indígenas, as empresas da borracha, a mineração, os reconhecimentos cartográficos, os projetos de elaboração de estradas e as orientações para a elaboração dos registros das políticas indigenistas (Timóteo da Cunha, 2016, 2017).

Apresento aqui os primeiros resultados da pesquisa. Indico alguns elementos da complexa rede de ações governamentais e científicas, amalgamadas a um processo de formação de Estado, produtoras de alteridades e mudanças sociais que estruturaram em determinadas proposições a formação de Rondônia. Ciente das lacunas, é oportuno frisar os apontamentos que indico as novas pesquisas que desejarem enveredar por esta seara, e alguns dos caminhos que proponho continuar. Apontar que a participação do SPI na formação de 
Rondônia se deu pela mediação, ao executar dispositivos de autoridade da tutela indigenista, são os elementos centrais para compreender a ação das políticas indigenistas na formação de Rondônia (Timóteo da Cunha, 2016).

\section{REFERÊNCIAS}

ALBERT, Bruce \& RAMOS, Alcida Rita. (Org.). Pacificando o Branco: Cosmologias do contato no NorteAmazônico. São Paulo; Unesp; 2002.

ARRUDA, Lucybeth Camargo de. Posto Fraternidade Indígena: Estratégias de Civilização e Táticas de Resistência 1913- 1945. Dissertação (Mestrado) Programa de Pós-Graduação em História Universidade Federal de Mato Grosso. 2003

"Faces do indigenismo oficial brasileiro - uma discussão sobre 'raças' indígenas via o SPI” In: Freire, Carlos Augusto da Rocha (Org.). Memória do SPI. Textos, imagens e documentos sobre o Serviço de Proteção aos Índios (1910-1967). Rio de Janeiro. Museu do Índio - FUNAI, p. 351-362. 2011

BAGOLIN, Darni Pillar. O indígena na república velha: as instituições de proteção no Rio grande do Sul. Dissertação de mestrado (Instituto de Filosofia e Ciências Humanas da Universidade do Passo Fundo). 2009

BARTH, F. "Grupos Étnicos e suas fronteiras”. In: POUTIGNAT, Philippe. Teorias da etnicidade. Seguido de grupos étnicos e suas fronteiras de Fredrik Barth. São Paulo: UNESP, 1998.

BENEVIDES, Marijeso de Alencar. Os novos territórios federais: Amapá, rio-Branco, Guaporé, Ponta-Porã e Iguaçu. Geografia, História e Legislação. Imprensa Nacional, RJ. 1946

BARTOLOMÉ, Miguel Alberto. "As Etnogêneses: velhos atores e novos papéis no cenário cultural e político". MANA 12(1): 39-68, 2000.

BIGIO, Elias dos Santos. Linhas telegráficas e integração de povos indígenas: as estratégias políticas de Rondon (1889-1930). Brasília: CGDOC/FUNAI. 2003.

BOURDIEU, Pierre. A Distinção: crítica social do julgamento. São Paulo: Edusp. 2008.

BERNARDINO, Maria Gabriela de Almeida. Um mapa para a república: a comissão da carta geral do Brasil (1903-1932). Dissertação (Mestrado em História das Ciências e da Saúde) -Fundação Oswaldo Cruz. Casa de Oswaldo Cruz. 2013

BRASIL. Mistério da Agricultura, indústria e comércio. Atividades do Mistério da Agricultura, indústria e comércio em 1909 e 1910. Rio de Janeiro: Mistério da Agricultura, indústria e comércio. Disponível em: http://brazil.crl.edu/bsd/bsd/u2000/contents.html. Acessado em: 01/02/2014. 1910.

Mistério da Agricultura. Atividades do Mistério da Agricultura durante no ano de 1938, apresentado pelo Ministro Fernando Costa. http://brazil.crl.edu/bsd/bsd/u2026/000001.html. Acessado em: 04/02/2014. 1939.

Mistério da Agricultura. Atividades agrícolas do brasil em 1939. Vol. I Apresentado pelo Ministro Fernando Costa. Disponível em: http://brazil.crl.edu/bsd/bsd/u2027/000001.html. Acessado em: 04/02/2014. 1940.

- Mistério da Agricultura. Atividades agrícolas do brasil em 1939. Vol. II Apresentado pelo Ministro Fernando Costa. Disponível em: http://brazil.crl.edu/bsd/bsd/u2028/000001.html. Acessado em: 04/02/2014. 1940.

CARDOSO DE OLIVEIRA, Roberto. "Aculturação e "fricção interétnica". América Latina , v. 6, n. 3, p. 33-46, 1963.

. Ação indigenista, eticidade e o diálogo interétnico. Estudos Avançados. 14 (40), 2000.

CANTANHEDE, Antônio. Achegas para a história de Porto Velho. Manaus: s/ed. 1950.

CARNEIRO DA CUNHA, Manuela. História dos índios no Brasil - FAPESP / NHII / SMC /Cia das Letras, 1992.

. \& VIVEIROS DE CASTRO, Eduardo. Amazônia, Etnologia e História Indígena - FAPESP/NHII/USP, 1993.

CHARTIER, Roger. A História Cultural. Entre Práticas e Representações. Lisboa/Rio de Janeiro: DIFEL/Bertrand Brasil. 1990.

CLAVAL, Paul. A geografia cultural. Florianópolis: Ed da UFSC. 2006 
COLFERAI, Sandro Adalberto. “A (re)invenção da Rondônia: dos sertões de Roquette-Pinto à Amazônia de Getúlio Vargas”. Novos Caderno NAEA. v.16 n.2 p.207-244, dez. 2013.

CORRÊA, Mariza. Antropólogas \& Antropologia. Belo Horizonte: Editora UFMG, 2003.

COSTA, Craveiro. A conquista do deserto ocidental. São Paulo, Companhia Editora Nacional. 1940.

CRAIG, Nevil B. Estrada de Ferro Madeira Mamoré: história trágica de uma expedição. São Paulo: Imprensa Nacional. 1947.

DAL POZ NETO, João. No país dos Cinta Larga: uma etnologia do ritual. São Paulo: USP. (Dissertação de Mestrado). 1991.

ERTHAL, Regina. Atrair e pacificar: a estratégia da conquista. Dissertação (Mestrado em Antropologia Social) - PPGAS/MN, UFRJ, Rio de Janeiro. 1992.

FERREIRA, Manoel Rodrigues. A Ferrovia do Diabo: história de uma estrada de Ferro na Amazônia. São Paulo: Melhoramentos. 1987.

FONSECA, Dante Ribeiro \& TEIXEIRA, Marco Antônio Domingues. História Regional (Rondônia). Porto Velho: Rondoniana. 2002.

. Estudos de História da Amazônia. Vol I. Porto Velho: Rondoniana. 2014.

FRANÇA, Luciana Barroso Costa. Caminhos cruzados: parentesco, diferença e movimento entre os Kagwahiva. Tese (Doutorado em Antropologia Social) - Universidade Federal do Rio de Janeiro, Museu Nacional, Programa de Pós-Graduação em Antropologia Social. 2012.

FREIRE, Carlos Augusto da Rocha. Indigenismo e Antropologia - O Conselho Nacional de Proteção aos Índios na gestão Rondon (1939-1955). Dissertação (Mestrado) Mestrado em Antropologia Social. Universidade Federal do Rio de Janeiro, UFRJ. 1990.

. Sagas Sertanistas: Práticas e Representações do Campo Indigenista no Século XX. Tese (doutorado) UFRJ/ MN/ Programa de Pós-graduação em Antropologia Social. 2005.

O SPI na Amazônia: Política indigenista e conflitos regionais (1910-1932). 1 a . ed. Rio de Janeiro: Museu do Índio. 2007.

. Rondon: A construção do Brasil e a causa indígena. 1. ed. Brasília: Abravídeo. 2009.

. Memória do SPI. Textos, imagens e documentos sobre o Serviço de Proteção aos Índios (1910-1967). Rio de Janeiro. Museu do Índio - FUNAI, p. 255-266. 2011

GAGLIARDI, José Mauro. O Indígena e a República. São Paulo: Editora Hucitec. 1989.

GALVÃO, Eduardo. Áreas Culturais indígenas do Brasil 1900-1959. In: Encontro de Sociedades Índios e Brancos no Brasil. Rio de Janeiro: Paz e Terra. 1960.

GALVÃO, Benjamin Franklin Ramiz. “Actas das sessões realizadas em 1913”. Revista do Instituto Histórico e Geográfico Brasileiro. Volume XX. Rio de Janeiro. p. 585-658. 1914.

HOERHANN, Rafael Casanova de Lima e Silva. O Serviço de Proteção aos Índios e os Botocudo: a política indigenista através dos relatórios (1912 - 1926). Dissertação (Mestrado de História do Curso de PósGraduação em História, Centro de Filosofia e Ciências Humanas, Universidade Federal de Santa Catarina). 2005.

O Serviço de Proteção aos Índios e a desintegração cultural dos Xokleng (1927-1954). (Tese de doutorado) - Universidade Federal de Santa Catarina, Centro de Filosofia e Ciências Humanas. Programa de Pós-Graduação em História. 2011.

HUGO, Vitor. Desbravadores. Humaitá. Vol I e II. 1959.

. Cinquenta ano do Território Federal do Guaporé. ABG gráfica. 1995.

KAFKA, Franz. "Durante a construção da muralha da China". IN: Narrativas do espólio. São Paulo: Companhia das letras. 2002

KUPER, Adam. A Reinvenção da Sociedade Primitiva. Transformações de um Mito. Recife, Editora Universitária - UFPE. 2008.

LEONEL, Mauro. Etnodicéia Uruéu-au-au. São Paulo: Edusp/IAMÁ/ FAPESP. 1996.

LOPES, Raimundo. Antropogeografia.Rio de Janeiro. Publicações Avulsas do Museu Nacional nº18. 1956.

LÉVINAS, Emmanuel. Entre nós. Ensaios sobre a alteridade. São Paulo: Editora Vozes, 2004.

LIMA, Nísia Trindade; HOCHMAN, Gilberto. Condenado pela raça, absolvido pela medicina: o Brasil descoberto pelo movimento sanitarista da Primeira República. In: Maio, Marcos Chor \& SANTOS, Ricardo Ventura (orgs.). Raça, Ciência e Sociedade. Rio de Janeiro: Fiocruz, p.23-40. 1996.

MALDI, Denise. Uma Etnografia e o seu propósito: os Suruí de Rondônia. Anuário Antropológico 85, Rio de Janeiro, p. 283-294, 1986. 1986.

. Guardiães da fronteira: rio Guaporé, séc. XVIII. Petrópolis, RJ: Vozes, 1989. 
. O complexo cultural do Marico: sociedades indígenas dos rios Branco, Colorado e Mequens, afluentes do Médio Guaporé. Boletim do Museu Paraense Emílio Goeldi, Belém, v. 7, n. 2, p. 219-269, 1991. (Série Antropologia).

MAUSS, Marcel. Sociologia e Antropologia. São Paulo: Cosac \& Naify. [1935] 2003.

MELATTI, Júlio Cesar Áreas Etnográficas da América Indígena. Disponível: http://www.juliomelatti.pro.br/areas/00areas.pdf. 2001.

MARTINS, Fernanda Santa Roza Ayala. O Serviço de Proteção aos Índios e localização de trabalhadores nacionais e a política na primeira república: grupos agrários, projetos e disputas no maranhão (19101918). Dissertação (mestrado de história social da Universidade Federal Fluminense - Rio de Janeiro). 2012.

MELO, Joaquim Rodrigues de. A política indigenista no Amazonas e o Serviço de Proteção aos Índios: 19101932. Dissertação (Mestrado) - Universidade Federal do Amazonas, Instituto de Ciências Humanas e Letras. 2007.

. “O SPI no Amazonas: 1910-1932” In: Freire, Carlos Augusto da Rocha (Org.). Memória do SPI. Textos, imagens e documentos sobre o Serviço de Proteção aos Índios (1910-1967). Rio de Janeiro. Museu do Índio - FUNAI, p. 403-418. 2011.

MENEZES, E. P. M. Retalhos para a História de Rondônia. Manaus, Imprensa Oficial do Estado do Amazonas. 1980.

MINDLIN, Betty. Demarcações paradas, prossegue a BR-364. In: Povos Indígenas no Brasil 1982. Aconteceu Especial 12. São Paulo, CEDI. 1982.

MOSER, Lilian. Os Karitiana e a colonização recente em Rondônia. Monografia de bacharelado, Universidade Federal de Rondônia. 1993.

OLIVEIRA, Humberto de. Coletânea de leis, atos e memoriais referentes ao indígena brasileiro. Rio de Janeiro: Imprensa Nacional. 1947.

OLIVEIRA FILHO, João Pacheco de. O nosso governo: Os Ticuna e Regime Tutelar. São Paulo: Marco Zero; Brasília. 1988

. (Org.). A viagem da volta: etnicidade, política e reelaboração cultural no Nordeste indígena. Rio de Janeiro, Contra Capa. 2004.

- \& FREIRE, Carlos Augusto da Rocha.. A presença indígena na formação do Brasil. Edições MEC/Unesco: Brasília. 2006

. "O paradoxo da tutela e a produção da indianidade: ação indigenista no Alto Solimões (1920-1970)". In: Freire, Carlos Augusto da Rocha (Org.). Memória do SPI. Textos, imagens e documentos sobre o Serviço de Proteção aos Índios (1910-1967). Rio de Janeiro. Museu do Índio - FUNAI, p. 427-442. 2011.

PARESCHI, A. C. Desenvolvimento sustentável e pequenos projetos: entre o projetismo, a ideologia e as dinâmicas sociais. Tese de Doutorado, Programa de Pós-Graduação em Antropologia Social, Universidade de Brasília, Brasília. 2002.

PEIRANO, Mariza G. S. “Antropologia no Brasil (Alteridade contextualizada)”. In: MICELI, Sergio. (Org.) $O$ que ler na ciência social brasileira. São Paulo: Editora Sumaré: ANPOCS; Brasília, DF: CAPES. 1999. pp: 225-266.

PERES, Sidnei. Arrendamento e Terras Indígenas. Análise de Alguns Modelos de Ação Indigenista no Nordeste (1910-1960). Dissertação (Mestrado) Programa de Pós-Graduação em Antropologia Social Universidade Federal do Rio de Janeiro. 1992.

RABELLO, Antônio Cláudio Barbosa. Inventando o outro: Representações do Desenvolvimento e da Fronteira amazônica. Tese Doutorado. Programa De Pós-Graduação em Desenvolvimento Sustentável do Trópico Úmido. 2004.

RIBEIRO, Darcy. A política indigenista brasileira. Rio de Janeiro: MA \& SIA. 1962.

PINTO, Nicole Soares. Do poder do sangue e da chicha: os Wajuru do Guaporé (Rondônia). Dissertação de mestrado, UFPR. 2009.

PINTO, E. P. Caiari: Lendas, Proto História e História de Rondônia. Rio de Janeiro, Expressão e Cultura. 1986. - Rondônia Evolução Histórica: A Criação do Território de Guaporé, Fator de Integração Nacional. Rio de Janeiro: Expressão e Cultura. 1993.

PRICE, David. Nambiquara Society. University of Chicago. (Tese de doutorado) 1972.

ROCHA, Leandro Mendes. A política indigenista no Brasil: 1930-1967. Goiânia, Editora UFG. 2003.

RONDON, Cândido Mariano da Silva. “Ofício no 54, de 10/02/1910”. In: Brasil. Ministério da Agricultura, Indústria e Comércio. Relatório do Ministério da Agricultura Indústria e Comércio. Rio de Janeiro: imprensa Nacional. 1910. 
. "Etnografia”. Revista brasileira de Geografia. 1940. Vol. 2 № 4, p. 594-621. 1940.

Índios do

Brasil: do centro ao noroeste e sul de Mato-Grosso. Rio de Janeiro: Imprensa Nacional. 1953

RONDON, Frederico Augusto. Na Rondônia Ocidental. Companhia Editoria Nacional: São Paulo, Rio de Janeiro, Recife, Porto Alegre. 1938.

ROQUETTE-PINTO, Edgar. Rondônia. 3 Ed. Biblioteca pedagogia brasileira, série V. Brasiliana, Vol. XXIX. 1935.

- Rondônia. 6 Ed. São Paulo: Ed. Nacional. Biblioteca pedagogia brasileira, série V. Brasiliana, Vol. XXIX. 1975 .

. Discurso de posse. Revista do Instituto Histórico e Geográfico Brasileiro. TOMO LXXVI parte II, Rio de Janeiro, p.p 587-597. 1914

SCHETTINO, Marco Paulo Fróes. "Áreas etnográficas: proposta de reestruturação do Departamento de Identificação e Delimitação da FUNAI com base na atuação em áreas etnográficas”. IN: BARRETO FILHO, Henyo Trindade \& SOUZA LIMA, Antonio Carlos. (org.), 2005. Antropologia e identificação: os antropólogos e a definição de terras indígenas no Brasil, 1977-2002. 2005.

SANTOS, Rita de Cássia Melo. No "Coração do Brasil”": Roquette Pinto e a Expedição à Serra do Norte (1912). Dissertação (mestrado) UFRJ/Museu Nacional/Programa de Pós-Graduação em Antropologia Social. 2011.

SANTOS, Ana Flávia Moreira. Conflitos fundiários, territorialização e disputas classificatórias. Tese Universidade Federal do Rio de Janeiro - MN/PPGAS. Rio de Janeiro. 2009

SEYFERTH, Geralda. "A Antropologia e a teoria do branqueamento da raça no Brasil: a tese de João Batista de Lacerda". Revista do Museu Paulista, São Paulo, Nova Série, (XXX), p. 81-92. 1985.

. 2008. "Roquette-Pinto e o debate sobre Raça e Imigração no Brasil". In: Antropologia brasiliana: ciência e educação na obra de Edgard Roquette-Pinto. LIMA, Nísia Trindade e SÁ, Dominichi Miranda de. (Org.). Belo Horizonte: Editora UFMG; Rio de Janeiro: Editora Fiocruz.

SOUZA LIMA, Antônio Carlos de Souza. Os fetichistas, ordem e progresso um estudo do campo indigenista no seu estado de formação. Rio de Janeiro: PPGAS / Museu Nacional. Dissertação de Mestrado em Antropologia Social. 1985.

- O governo dos índios sob a gestão do SPI. In: Carneiro da Cunha, Emanuela. História dos índios no Brasil. São Paulo: Companhia das letras, FAPESP. 1992.

- Um Grande Cerco de Paz: poder tutelar, indianidade e formação do Estado no Brasil. Petrópolis: Vozes. 1995.

- "Reconsiderando poder tutelar e formação do Estado no Brasil: notas a partir da criação do Serviço de Proteção aos Índios e Localização dos Trabalhadores Nacionais”. In: Freire, Carlos Augusto da Rocha (Org.). Memória do SPI. Textos, imagens e documentos sobre o Serviço de Proteção aos Índios (19101967). Rio de Janeiro. Museu do Índio - FUNAI, p. 201-212. 2011.

SOUZA, Vanderlei Sebastião de. Em busca do Brasil: Edgard Roquette-Pinto e o retrato antropológico brasileiro (1905-1935). Tese (Doutorado em História das Ciências e da Saúde) - Fundação Oswaldo Cruz. Casa de Oswaldo Cruz. 2011.

TIMÓTEO DA CUNHA, Eliaquim. Em busca da "vida de índio”: Um estudo sobre mudanças sociais pensadas pelo grupo Cassupá em Rondônia. Trabalho apresentado na 29a Reunião Brasileira de Antropologia, realizada entre os dias 03 e 06 de agosto de 2014, Natal/RN.

"Quando esse tal de SPI" chegou: O serviço de Proteção aos Índios na Formação de Rondônia. Dissertação (Mestrado) em Antropologia Social - PPGAS/UFAM. Manaus. 2016.

. "Da tutela ao protagonismo: a trajetória Cassupá em Rondônia". In: Dossiê - Remoções forçadas de grupos indígenas no Brasil republicano. Mediações, Londrina, V. 22 N. 2, P. 223-276, JUL./DEZ. 2017.

TOMEI, Manuela \& SEWPSTON, Lee. Povos indígenas e tribais. Guia para a aplicação da convenção $n 169$ da OIT. Brasília, OIT. 1999.

VANDER VELDEN, Felipe. "Os Tupí em Rondônia: diversidade, estado do conhecimento e propostas de investigação". Revista Brasileira de Linguística Antropológica. Vol. 2 , n. 1, Jul. 2010.

VILAÇA, Aparecida. Quem somos nós. Os Wari' encontram os Brancos. Rio de Janeiro. Editora da UFRJ. 2006.

VIVEIROS, Esther de. Rondon conta sua vida. Rio de Janeiro, Livraria São José. 1969.

WAGNER, Roy. A Invenção da cultura. São Paulo: Cosac Naify, 2010. 